\title{
Review \\ Novel Therapeutic Approaches to Psoriasis and Risk of Infectious Disease
}

\author{
Alfonso Motolese ${ }^{1}$, Manuela Ceccarelli ${ }^{2,3}$, Laura Macca ${ }^{1} \mathbb{D}$, Federica Li Pomi ${ }^{1}\left(\mathbb{D}\right.$, Ylenia Ingrasciotta ${ }^{4}$, \\ Giuseppe Nunnari ${ }^{5}$ and Claudio Guarneri ${ }^{6, *(D)}$
}

1 Department of Clinical and Experimental Medicine, Section of Dermatology, University of Messina, Messina, Italy C/O A.O.U.P. "Gaetano Martino", via Consolare Valeria, 1, 98125 Messina, Italy; alfonsomotolese93@gmail.com (A.M.); lauramacca7@gmail.com (L.M.); federicalipomi@hotmail.it (F.L.P.)

2 Department of Clinical and Experimental Medicine, Unit of Infectious Diseases, University of Catania, Catania, Italy C/O ARNAS “Garibaldi”, “Nesima” Hospital, via Palermo 636, 95122 Catania, Italy; manuela.ceccarelli@unict.it

3 Department of Biomedical and Dental Sciences and Morphofunctional Imaging, Unit of Infectious Diseases, University of Messina, Messina, Italy C/O A.O.U.P. “Gaetano Martino", via Consolare Valeria, 1, 98125 Messina, Italy

4 Department of Biomedical and Dental Sciences and Morphofunctional Imaging, Section of Pharmacology, University of Messina, Messina, Italy C/O A.O.U.P. “Gaetano Martino", via Consolare Valeria, 1, 98125 Messina, Italy; yingrasciotta@unime.it

5 Department of Clinical and Experimental Medicine, Unit of Infectious Diseases, University of Messina, Messina, Italy C/O A.O.U.P. “Gaetano Martino”, via Consolare Valeria, 1, 98124 Messina, Italy; giuseppe.nunnari@unime.it

6 Department of Biomedical and Dental Sciences and Morphofunctional Imaging, Section of Dermatology, University of Messina, Messina, Italy C/O A.O.U.P. "Gaetano Martino", via Consolare Valeria, 1, 98125 Messina, Italy

Citation: Motolese, A.; Ceccarelli, M.; Macca, L.; Li Pomi, F.; Ingrasciotta, Y.; Nunnari, G.; Guarneri, C. Novel Therapeutic Approaches to Psoriasis and Risk of Infectious Disease.

Biomedicines 2022, 10, 228.

https://doi.org/10.3390/

biomedicines 10020228

Academic Editor: Emanuela Martina

Received: 2 January 2022

Accepted: 18 January 2022

Published: 21 January 2022

Publisher's Note: MDPI stays neutral with regard to jurisdictional claims in published maps and institutional affiliations.

Copyright: (C) 2022 by the authors. Licensee MDPI, Basel, Switzerland. This article is an open access article distributed under the terms and conditions of the Creative Commons Attribution (CC BY) license (https:// creativecommons.org/licenses/by/ $4.0 /)$.

* Correspondence: cguarneri@unime.it; Tel.: +39-090-2212-894; Fax: +39-09-029-27691

\begin{abstract}
Psoriasis is a chronic immune-mediated skin and joint disease, with a plethora of comorbidities, characterized by a certain genetic predisposition, and a complex pathogenesis based on the IL-23/IL-17 pathway. There is no doubt that the patients affected by psoriasis are more susceptible to infections as well as that the risk of infection is higher in psoriatic subjects than in the general population. The advent of biotechnological agents on the therapeutic arsenal actually available for the treatment of moderate-to-severe patients, given the fact that the severity of the disease is a predictor of the level of infectious risk, has raised the question of whether these 'new' drugs could be considered a safer option and how they can be used in selected cases. Old and newer strategies in cases of chronic infectious conditions are reviewed under the light of clinical trials and other studies present in literature.
\end{abstract}

Keywords: psoriasis; infections; HIV; HBV; HCV; tuberculosis; COVID-19; anti-TNF- $\alpha$; antiIL-23; anti-IL-17; anti-IL12/23; anti-PDE4; anti-JAK

\section{Introduction}

Psoriasis is a chronic and recurrent inflammatory disease predominantly involving the skin [1]. It is characterized by well-defined, scaly, erythematous plaques, occasionally covered with silvery scales [1]. Lesions appear especially over the extensor surfaces, scalp, and lumbosacral region, but any skin surface can be involved [2]. Psoriasis is considered a common disease with an incidence of about $1-3 \%$ in the world population, and it affects men and women equally [3,4]. The pathogenesis of psoriasis involves a feed-forward mechanism of inflammation, including primarily the T-helper cell type 17 (TH17) and IL-23 pathway [1]. The dendritic cells, activated by numerous cytokines produced by keratinocytes, natural killer T-cells, and macrophages, secrete IL-12 and IL-23 inducing the differentiation of native T-cells to TH1 cells and the survival and proliferation of TH17 and 
TH22 cells $[1,5,6]$. This results in the production of several pro-inflammatory cytokines, such as IFN $\gamma$, TNF $\alpha$ and IL-22 [1], which are conducive to the proliferation of downstream keratinocyte, to the increased expression of angiogenic mediators and endothelial adhesion molecules, and to the infiltration of immune cells into lesional skin [7]. It is important to note that, as in multifactorial diseases, genetic factors have a critical role in the pathogenesis of psoriasis [5], and environmental factors can exacerbate the manifestations [5]. Psoriasis is associated with several comorbidities, including psoriatic arthritis cardiometabolic diseases, depression [5,8-10]; it is also associated with infectious diseases such as HIV, of which it is a revealing sign [11]. In fact, despite the availability of numerous systemic agents, choosing the right therapy might be challenging in certain categories of patients [6]. Psoriasis Area Severity Index (PASI) score is the most used tool to evaluate the severity of psoriasis and the outcome of the treatments [6]. During the last decades, the incidence of psoriasis increased and the deeper understanding of the pathogenesis led to a development of novel therapeutic approaches [1]. Tumor necrosis factor (TNF)- $\alpha$ antagonists totally changed the clinical history of the management of psoriasis and research interest is high in the newest biological drugs approved, especially drugs blocking IL-23/IL-17 [12]. While these therapies appeared to be effective in clearing cutaneous manifestations, their adverse event profiles frequently include infections [13]. The aim of our review is to analyze the new therapeutic approaches for the treatments of psoriasis, the potential risk of infections caused by these agents and the treatment strategies for patients with concomitants chronic infections.

\section{Materials and Methods}

Articles derived from the database Pubmed (https://ncbi.nlm.nih.gov/PubMed, accessed on 1 April 2021) and Embase (https://embase.com, accessed on 1 April 2021), published between 2018 and 2021. The keywords used were ("psoriasis") AND ("infection", "biologic", "TNF- $\alpha$ inhibitors", "IL-17 inhibitors", "IL-12/23 inhibitors", "IL-23 inhibitors", "anti-PDE4", "anti-JAK"). Only papers written in English were considered. Data were extracted and selected by two experts in the field of dermatology.

\section{Discussion}

\subsection{Risk of Infection in Psoriasis}

Infectious diseases are the second leading cause of death among psoriasis patients receiving therapies for moderate-to-severe disease [14]; however, the mechanism by which psoriasis predisposes to infection is still unclear [13]. According to some, patients with psoriasis have multiple risk factors for serious infections, such as immune dysregulation characterized by an increase of TNF and IL-17, and the use of systemic immunosuppressants $[15,16]$. The increased risk of infections caused by psoriasis is extensively documented in the literature [15,17-19]. As shown by Yiu et al. [18], there is a concrete risk of serious infection in psoriatic patients (20.5\% per 1000 person-years) compared with those without psoriasis (16.5 per 1000 person-years), especially across the respiratory system and the soft-tissue/skin, which are the most common infection sites [18]. Hsu et al. [19] studied the association between psoriasis and the risk of infections in patients in the United States, showing that psoriatic patients are more prone to the risk of multiple infectious diseases, including viral infections, fungal infections, cellulitis, and infectious arthritis. The study also underlined that infections including pneumonia, septicemia, enterocolitis, meningitis, encephalitis, and peritonitis lead to the highest mortality rates [19]. In addition, it is important to also consider the significant impact of these serious infections on costs of care for patients: the study shows that the mean cost of care for patients with psoriasis and any serious infection is considerably higher (USD 13,291 6 USD 166) than for psoriatic patients that do not present such serious infections (USD 11,003 6 USD 96) [19]. To evaluate the risk of infection, it is important to consider the gravity of psoriasis. In fact, Takeshita et al. [15] found that the risk of having serious infection was higher for patients with moderate-severe psoriasis (49.5 per 10,000 person-years) compared with mild psoriasis (14.4 per 10,000 person-years). According to this study, psoriasis severity is a predictor of 
serious infection risk beyond traditional risk factors for infection [15]. In contrast, higher risks of opportunistic infections and herpes zoster were essentially limited to those patients receiving therapies for moderate-to-severe psoriasis and were associated with immunosuppressive therapies $[15,20]$. Moreover, the majority of the new systemic agents for psoriasis are immunosuppressive, which determine a singular treatment challenge in patients with psoriasis with chronic infections, such as tuberculosis, HIV, and hepatitis, because of their immunosuppressed profile [21]. Factors to consider when selecting systemic treatment during infections are summarized in Table 1.

Table 1. Factors to consider when selecting systemic treatment during infections.

\begin{tabular}{cccccc}
\hline Class of Drugs & Drug & TBC & HIV & HBV & HCV \\
\hline TNF-a inhibitors & Etanercept & + & ++ & + & ++ \\
\hline & Adalimumab & -+ & ++ & + & + \\
\hline & Infliximab & -+ & ++ & ++ & $?+$ \\
\hline IL-23 inhibitors & Certolizumab & -+ & $?+$ & $?+$ & $?+$ \\
\hline & Guselkumab & ++ & $?+$ & $?+$ & $?+$ \\
\hline IL-17 inhibitors & Secukinumab & ++ & ++ & ++ & $?+$ \\
\hline & Ixekizumab & ++ & ++ & $?+$ & $?+$ \\
\hline IL-12/23 inhibitors & Ustekinumab & ++ & ++ & $?+$ & $?+$ \\
\hline PDE4 inhibitors & Apremilast & ++ & ++ & ++ & $?+$ \\
\hline JAK inhibitors & Tofacitinib & + & ++ & $?$ & $?+$
\end{tabular}

Note: Two plus symbols (++) indicates preferred agents; one plus syndrome (+) indicates that the agent can be used; one plus symbol and one minus symbol (+-) indicate that the drug can be used but is controversial; one minus symbol and one plus symbol $(-+)$ indicate that the drug is not preferred but can be used; one question mark and one plus symbol (?+) indicate that there are not enough data but the drug is likely safe to use; one question mark (?) indicates that there are not enough data; one minus symbol (-) indicates that use of that drug is controversial because there are not enough data; and $(\mathrm{x})$ indicates that the drug is contraindicated.

\subsection{Tubercolosis}

Tuberculosis (TB) is the world's most deadly infectious disease with 1.5 million deaths per year [22]. Once infected, the individual is at the highest risk of developing TB disease within the first two years but can remain at risk for their lifetime [22]. In the majority of immunocompetent individuals, TB infection is contained by host defense mechanisms, resulting in latent TB infection (LTBI). Tumor necrosis factor alpha (TNF- $\alpha$ ) plays a major role in the host response to $\mathrm{TB}$ and confinement of the mycobacteria by the formation of the granuloma [23]. Moreover, IL-17/IL-23 axis is crucial in the immune response to Mycobacterium infections both in the innate and in the adaptive immune response, stimulating the production of antimicrobial peptides and the induction of protective T-cells [24]. In fact, chronic immunosuppression is a well-known risk factor for allowing latent tuberculosis (TB) infection to transform into active TB [25]. Therefore, before starting an immunosuppressive therapy to treat psoriasis, it is critical that the patient is screened for latent tuberculosis infection (LTBI). The patient should undergo at least an interferon-gamma release assay (IGRA) or tuberculin skin test (TST) and their clinical history and physical examination should be investigated in full. If the screening laboratory tests result is positive, further medical evaluation is required, with a chest X-ray or computed-tomography scan. If the chest X-ray results negative, the diagnosis is of LTBI it is recommended to start either 9 months of isoniazid $5 \mathrm{mg} / \mathrm{kg}$ daily with pyridoxine or 3 months of isoniazid $5 \mathrm{mg} / \mathrm{kg}$ daily plus rifampin $10 \mathrm{mg} / \mathrm{kg}$ daily plus pyridoxine with the objective of starting the biologic therapy only after completion of 1 to 2 month of prophylaxis treatment $[25,26]$. 
Additional clinical investigation should be conducted if symptoms or signs suggestive of TB, or new exposure to TB or continued residence in a high-incidence setting should occur, including a repeat interferon-gamma release assay in previously negative patients [25]. If a patient develops active TB while taking immune suppressant drugs, the immunosuppressant treatment should be stopped and the standard therapy for tuberculosis should be started [27].

\subsubsection{ANTI-TNF $\alpha$}

TNF-a plays a fundamental role in the macrophage response and in the tubercular granuloma formation and the use of TNF-a inhibitors (TNFi) in patients with psoriasis has been associated with tuberculosis reactivation or disease worsening [28,29]. In addition, atypical presentations of TB, such as disseminated and extrapulmonary disease, are more common in the setting of treatment with anti-TNF-a, as it has been reported by Cortez de Almeida et al. [30,31]. They presented a case series of two patients, who tested negative to TST screening test, showing disseminated TB after adalimumab treatment. They both reached complete resolution after having suspended TNFi treatment and having completed the anti-tubercolosis standard therapy [31]. Moreover, Cantini et al. demonstrated that patients with LTBI receiving TNFi therapy for rheumatoid arthritis or psoriasis have approximately a fourfold increase in the risk of developing active TB compared with control patients [32]. In a three-year French study, Tubach et al. highlighted that the risk of tuberculosis is three to four times higher with the use of monoclonal antibodies (MAbs), such as adalimumab, infliximab and certolizumab, compared with etanercept [33]. In fact, MAbs can induce apoptosis in TNF-a-expressing T-cells by the cross-linking of membrane-associated TNF-a and through complement- or anti- body-dependent cellmediated cytotoxicity [26]. As shown in a study collecting the results of 18 controlled trials among a total of 3723 patients with psoriasis, cases of tuberculosis were found in 16 cases [34]. Of these, 7 cases of LTBI and 9 cases of active tuberculosis were found [34]. A pooled analysis of controlled trials for numerous conditions highlighted only one case of tuberculosis in patients on certolizumab [35]. A study comparing drugs for dermatologic and rheumatologic conditions with infliximab revealed that between 1998 and 2001, a total of 70 cases of active tuberculosis after treatment initiation were reported in the FDA's Adverse Event Reporting System FAERS [28]. Today TNFi is considered a lastline option for the treatment of tuberculosis given its increased risk of serious infection and the availability of safer options. In patients with LTBI at least 1 month of treatment to address it is recommended before initiating the therapy.

\subsubsection{ANTI-IL-23}

The IL-23 selective inhibitors that are approved by the US Food and Drug Administration to treat plaque psoriasis in adults are guselkumab, tildrakizumab, and risankizumab. In a two pooled study of phase 3 assessing the safety of guselkumab and anti-tuberculosis treatment (VOYAGE 1 and VOYAGE 2), no cases of active TB, including reactivation of LTBI, were reported in patients with or without LTBI treated for up to 2 years [36,37]. No cases of tuberculosis were reported in 534 patients treated with guselkumab included in the ECLIPSE trial [38]. Blauvelt et al. did not register any cases of tuberculosis in a clinical trial about continuous risankizumab therapy [39]. Moreover, in a study by Huang et al. 31 patients tested positive for LTBI by IGRA test and were left untreated for the infection while under therapy with risankizumab [40]. None of these patients developed tuberculosis reactivation during 55 weeks of follow-up [40]. In addition, no cases of tuberculosis were highlighted in two phase 3 tildrakizumab clinical trials [41]. Since low rates of tuberculosis reactivation have been reported and their favorable long-term safety profiles also in association to LTBI infection treatment, IL-23 inhibitors are considered a first-choice approach for the treatment of plaque psoriasis. 


\subsubsection{ANTI-IL-17}

So far, no cases of LTBI reactivation have been reported with IL-17-blockers. Therefore, IL17A-inhibitors are considered a safe choice to treat patients affected by psoriasis with LTBI [21,42]. In several studies, it was shown that during secukinumab treatment there were no cases of opportunistic or active $\mathrm{TB}$, as in either new infections or reactivations of LTBI $[43,44]$. In an analysis of five phase 3 studies assessing the safety profile of secukinumab, 107 subjects out of 132 received anti-tuberculosis medication after a positive IGRA test, and 25 patients that had a negative test received secukinumab without previous anti-tuberculosis treatment [45]. No cases of active TB were reported in either group [45]. Yamaguchi et al. did not highlight any case of active TB in 129 Japanese patients treated with brodalumab for 64 weeks [46]. In addition, in the long-term extension of the phase 3 clinical trials, UNCOVER-1 and UNCOVER-2, no cases of TB reactivation were diagnosed in patients on Ixekizumab. However, one case of 'de novo' LTBI was reported, and the patient completed the trial after being treated with isoniazid [47].

\subsubsection{ANTI-IL12/IL23}

The IL-12 and IL-23 immuno-response pathway is important for host protection against infections and intracellular pathogens. Ustekinumab targets the shared p40 subunit of IL-12 and IL-23 cytokines and was approved to treat plaque psoriasis. Tsai et al. reported 1 case of latent TB reactivation in a patient with psoriasis receiving ustekinumab without concomitant isoniazid treatment [48]. In 5 phase 3 trials of 3177 patients treated with ustekinumab, 167 subjects were LTBI+ and were treated concomitantly with isoniazid prophylaxis. No TB reactivation was observed, and isoniazid was well-tolerated [48]. From the analysis of a national database in South Korea, it was shown that ustekinumab did not increase the risk of TB compared to that among the general population in a realworld clinical setting [49]. In addition, Hsiao et al. reported no cases of TB reactivation in 134 patients treated with ustekinumab [50].

\subsubsection{ANTI-PDE4}

Phosphodiesterase-4 (PDE4) is the major enzyme class responsible for the hydrolysis of cyclic adenosine monophosphate (cAMP), an intracellular second messenger that controls a network of pro-inflammatory and anti-inflammatory mediators [51]. Apremilast is a drug marketed for the treatment of psoriasis and psoriatic arthritis that, by the inhibition of the breakdown of cyclic adenosine monophosphate (cAMP), results in decreased production of inflammatory cytokines [5]. Serious opportunistic infections were comparable between placebo and apremilast in trials and no cases of LTBI reactivation have been showed so far in patients treated with apremilast [51,52]. Hagberg et al. [53] studied the risk of infections and TB with apremilast compared to DMARDs and biological drugs to treat psoriasis, showing that the incidence rates were low with the PDE4-inhibitor (0.2 per 1000 person-year).

\subsubsection{ANTI-JAK}

The Janus kinase (JAK)-signal transducer and activator of transcription (STAT) signaling pathway plays critical roles in modulating the immune system [54]. Inhibition of Janus kinase 3 (JAK3) in T-cells is expected to block T-cell receptor-triggered signaling from downstream events and could be effective in T-cell-mediated disorders such as psoriasis [55]. Tofacitinib, by blocking the Jak-signaling, has a direct impact on dysregulated keratinocytes leading to a reduction in inflammatory infiltrates and normalization of the interleukin (IL)-23/Th17 axis [56]. The efficacy and safety of tofacitinib, the only drug in the class approved for the treatment of moderate-severe plaque psoriasis, have been demonstrated in a phase III study [54]. In an integrated long-term phase 3 study involving 6194 patients treated for up to 8.5 years with tofacitinib it was shown that 36 patients developed TB, giving an overall incidence rate of 0.2 (95\% CI: 0.1-0.3) per 100 person-years [57]. In phase III studies, 263 patients diagnosed with LTBI at screening were treated with isoniazid concurrently with tofacitinib and none developed active TB [58]. 


\subsection{HIV}

It is known that people affected by HIV suffer a higher incidence of skin disorders, often associated with elevated morbidity [11]. Most notably, psoriasis affects HIV patients much more acutely than the general population, and usually for a longer period of time [11]. Moreover, the treatment choice for psoriasis in HIV infection is limited by systemic immunosuppression associated with some systemic and biological treatment regimens [59]. As is known, the pathogenesis of psoriasis is associated with the activation of T-cells and the treatments that reduce the T-cell count improve psoriasis. On the other hand, HIV infection is characterized by a progressive decrease in CD4+ T-cell count, and it could seem paradoxical that psoriasis exacerbations are more frequent in this subset of patients than the general population [60]; however, when psoriasis is associated with HIV infection, it is more severe due to the low control of the immune response: it was shown that with a CD4+ T-cell count $<200 / \mu \mathrm{L}$, there is a risk 9-fold greater of a severe form [61]. Moreover, HIV infection is characterized by an increased CD8+ T-cell number with an inverted CD4+/CD8+ ratio suggestive of a chronic inflammatory status, which could lead to the onset of psoriasis [61]. In fact, these patients should be managed in collaboration with infectious disease specialists for close monitoring of plasma viral load and CD4+ T-cell count. As preliminary screening for the use of immunosuppressant drugs for the treatment of psoriasis, an HIV serological testing with fourth generation enzyme-linked immunosorbent assay (ELISA) method combining the research for both antibodies and p24 antigen should be performed. If positive, HIV infection should be confirmed by either wester-blotting or NAT. The staging of the infection includes CD4 cells count and plasma HIV-RNA. Biological drugs should not be administered if the CD4+ T-cell count is lower than $200 / \mu \mathrm{L}$ [21].

\subsubsection{ANTI-TNF-a}

The use of TNF-a inhibitors in HIV patients has been associated with an increased risk of opportunistic infections [62]. In a study by Cepeda et al. [63], 8 patients were treated with etanercept or infliximab and none of them developed either opportunistic or infectious diseases. Moreover, the CD4+ T-cell count remained stable. Adalimumab was also shown to have a good safety profile in a study by Lindsey et al. [64], with increment of the CD4+ T-cell count. In a study evaluating the use of etanercept in HIV-1-associated tuberculosis, there were no increased infectious complications in those $16 \mathrm{HIV}$-infected individuals receiving etanercept compared with the $42 \mathrm{HIV}$-infected control patients [65]. In an Italian experience by Bardazzi et al. [66], none of the 8 patients treated with TNF-a inhibitors (6 with etanercept and 2 with adalimumab) developed infectious diseases or had to interrupt the treatment because of severe immune suppression [66]. All the patients reached PASI 75\% after 3 months and showed overall stable levels of CD4+ T-cell count. The data presented allow to deem TNFis as safe in the setting of HIV infection, when respecting the contra-indication of a CD-4+ T-cell count lower than 200 cells $/ \mu \mathrm{L}$.

\subsubsection{ANTI-IL-23}

There are few published studies regarding the use of IL-23 inhibitors in HIV patients. Bartos et al. [67] did not report any adverse events in one HIV-patient successfully treated with guselkumab with CD4+ counts slightly decreased after 1 year.

\subsubsection{ANTI-IL-17}

The literature evaluating the treatment with secukinumab of patients who are HIVpositive is limited. In a case report by Di Lernia et al. [68], a 48-year-old HIV-positive woman was successfully treated with secukinumab, with no adverse reports reported, and remained free of psoriatic lesion at follow-up visit at 12 months. Moreover, in a case series by Pangilinan et al. [69], 2 HIV-positive patients affected by erythrodermic psoriasis were treated with secukinumab and ixekizumab and registered a great improvement of PASI with no adverse events occurrences [69]. However, the well-known risk of fungal infections 
related to IL-17 use limits their use in immunodeficient patients, such as those who are HIV-affected [59].

\subsubsection{ANTI-IL12/IL23}

There are numerous reports of successful administration of ustekinumab in HIVpositive patients affected by psoriasis $[66,70]$. Bardazzi et al. treated 4 patients for a mean duration therapy of 34.8 months with ustekinumab and adverse events were not reported, including serious and opportunistic infections [66]. It is demonstrated that the CD4+ T-cell count as well as the viral load not only remain stable, but also improve in some cases $[66,71]$. Ustekinumab not only shows a good safety profile but also seems to achieve good therapeutic outcomes, with an improvement of PASI and patients' quality of life, making it among the first-line drugs [66]

\subsubsection{ANTI-PDE4}

Several case reports have been published recently regarding the use of apremilast in HIV patients affected by psoriasis [72-75]. Neither opportunistic nor serious infectious disease were reported. Moreover, apremilast was shown to be safe and succesful in complex patients co-infected with HIV and either HCV or HBV [74,75]. Due to its "low" immunosuppressive properties, apremilast should be considered a first-line treatment in HIV patients.

\subsubsection{ANTI-JAK}

No data were published during the last three years about the use of tofacitinib in patients with HIV infection and psoriasis.

\section{4. $H B V$}

While the association between psoriasis and hepatitis $C$ has been demonstrated, hepatitis $B$ risk of infection seems not to be correlated to psoriasis [76,77]. In a multivariate analysis by Cohen et al. [76] it was found that the prevalence of psoriasis was not significantly associated with hepatitis $B(O R=1.22,95 \% C I=0.93-1.60)$. Before starting a systemic therapy with immune suppressive drugs, patients must be screened for hepatitis $\mathrm{B}$ virus (HBV) infection, looking for the presence of antibodies directed against $\mathrm{HBV}$ core (HBcAb) and HBV surface antigen (HBsAb). Moreover, HBV surface antigen (HBsAg) should be searched. If HBsAg results are positive, with the absence of $\mathrm{HBs} \mathrm{Ab}$, it indicates that the patient has either recently been infected with HBV or at all [78]. Plasma HBV-DNA should be measured and treatment for the infection should be started. If $\mathrm{HBcAb}$ is found positive, in absence of HBsAg, this is called "occult hepatitis B" [78]. It must be determined if we are in presence of an active or inactive carrier by measuring plasma HBV-DNA, quantitative $\mathrm{HBsAg}, \mathrm{HBeAg}, \mathrm{HBeAb}$ (IgG). When plasma HBV-DNA is detectable, treatment with entecavir or tenofovir should be started before biological treatment [78]. Biological treatment should be initiated when plasma HBV-DNA is either undetectable or at least lower than $2000 \mathrm{UI} / \mathrm{mL}$ [79]. If plasma HBV-DNA is not detectable, it is recommended to start lamivudine (100 mg/daily) 2 weeks before biological drugs and continue up to the end of therapy. $\mathrm{HBcAb}$ appears with acute infection and persists for life, prophylaxis is not required when Abs are the only sign of the infection, but clinical and laboratory monitoring is recommended [79]. The isolated presence of HBsAb indicates either recovery or immunity because of vaccination and no measures are required [21].

\subsubsection{ANTI-TNF-a}

TNF- $\alpha$ plays an important role in the clearance of hepatitis B virus from infected hepatocytes, therefore TNFi may lead to hepatitis reactivation or disease worsening. An analysis of $257 \mathrm{HBsAg}$ or anti-HBc-positive patient receiving TNFi showed HBV reactivation in 39\% of $\mathrm{HBsAg}$ positive patients compared with $5 \%$ of isolated anti-HBc positive patients [80]. HBV reactivation was more frequent in patients who did not undergo antiviral prophylaxis 
compared with patients who did (62\% vs. $23 \%$ ). Patients with HBcAb positivity pose a lower risk of viral reactivation compared with patients with HBsAg positivity [80]. All the molecules belonging to TNF $\alpha$ inhibitors have been shown to be associated with druginduced liver injury; therefore, it is highly recommended to monitor the liver enzymes during the therapy [81]. If the patient is $\mathrm{HBsAg}+/$ anti-HBc+, antiviral prophylaxis should be commenced concomitantly or 1-2 weeks before TNFi therapy is initiated. The duration of treatment should be decided with the hepatologist [80]. On the other side, when the patient is HBsAg-/anti-HBc-, vaccination should be considered 2 weeks before starting biological therapy. However, a consultation with hepatologist and a triple serology screening with LFTs is highly recommended before starting the TNFi therapy in order to have a serologic risk stratification between nonimmune, immune due to vaccination, resolved previous hepatitis infection, acute infection, chronic infection, and occult infection and decide an appropriate initiation of antiviral prophylaxis and/or vaccination.

\subsubsection{ANTI-IL12/23}

The role of IL-23 in immune response to hepatotropic viruses is still unclear [82]. According to literature, only two cases of patients (one pediatric), both treated with ustekinumab and then guselkumab and having respectively HBsAg negativity and HBsAg/anti$\mathrm{HBcAg}$ positivity have been reported. Of note, the pediatric case had most likely acquired HBV and was considered to be in a chronic inactive carrier state. In both cases, no reactivation occurred, liver enzymes remained stable, and HBV-DNA of pediatric patient progressively decreased to become undetectable [82,83]. Ustekinumab seems to be associated with a moderate risk of reactivation, according to the few data available in literature (10 studies, 3 patients with HBV reactivation, one also using MTX, only one receiving prophylaxis with lamivudine) [84].

\subsubsection{ANTI-IL17}

The hypothesis of a possible beneficial role of Il-17 inhibitors on the development of liver fibrosis still needs to be confirmed [84]. Regarding the real-world data, few cases have been reported. In one prospective study performed on $49 \mathrm{HBV}$ patients, only 4 reactivations were reported out of $22 \mathrm{HBsAg}+$ treated patients and only one out of 24 in $\mathrm{HBsAg-/anti-}$ $\mathrm{HBc}+$ subjects. No reactivation was found in the three remaining $\mathrm{HBsAg}+$ patients receiving antiviral treatment [85]. Cases of chronic or resolved HBV infection in patients undergoing secukinumab therapy have been reported [86,87], but none were found to have hepatitis or virus reactivation. A good safety profile was shown also for ixekizumab: 2 reports in the literature (one with active HBV infection and concurrently treated with entecavir and one with both markers of past HBV infection and anti-HCV positivity and no signs of reactivation) suggest the drug as safe in this setting [88,89]. No cases of reactivation of HBV have been reported in randomized controlled trials of brodalumab and its safety has not been yet established in HBV or HCV patients by real-world data [84].

\subsubsection{ANTI-PDE4}

Given the mechanism of action, apremilast represents a safe option in conditions in which immunosuppression is contraindicated and has no hepatotoxic effects [90]. In addition, the anti-fibrotic action showed in animal models by inhibiting pro-fibrotic factors such as TGF $\beta$ and IL-13, highlighted a potentially positive impact on liver fibrosis [84] Only one case in literature has been described of a patient with chronic viral hepatitis $B$ treated with apremilast with no concomitant antiviral treatment [75]. The liver function tests consistently remained within normal ranges after 1 year, and HBV-DNA was always negative.

\subsubsection{ANTI-JAK}

No data were published during the last three years about the use of tofacitinib in patients with HBV infection and psoriasis. 


\section{5. $\mathrm{HCV}$}

Several studies showed a higher prevalence of $\mathrm{HCV}$ infection in patients with psoriasis $[76,77,91]$. In a large cohort study by Cohen et al. [76] among 12.000 patients, it was shown that the prevalence of hepatitis $C$ in psoriatic patients was $1.03 \%$, compared to $0.56 \%$ in controls. This could be explained by the increased cutaneous levels of cathelicidin, TLR9, and IFNc of HCV-positive psoriatic patients in comparison to HCV-negative psoriatics, suggesting that $\mathrm{HCV}$ infection may predispose patients to developing psoriasis [92]. HCV infection is diagnosed when anti-HCV antibodies are detected. A patient with a positive result must undergo HCV-RNA testing, or HCV-core-antigen testing whenever HCV-RNA assays are uunavailable or not affordable, to diagnose an active infection [93]. If HCV-RNA is positive, it is mandatory to test liver functions and to start antiviral treatment with direct-acting antivirals (DAA), which are effective in eradicating the infection; biological therapies should not be commenced if cirrhosis is not controlled [79]. Unlike HBV reactivation, $\mathrm{HCV}$ reactivation is quite uncommon, occurring primarily with immunosuppressive drugs administered to chronically infected patients who were not carefully evaluated and did not receive antiviral therapy [94].

\subsubsection{ANTI-TNF-a}

The suppression of TNF- $\alpha$ by biological agents was considered to be a possible threat to viral replication and possible chronic $\mathrm{HCV}$ infection. On the contrary, a high production of TNF- $\alpha$ was found in patients chronic HCV infections, with implications for liver injury [95]. Among TNFi, the use of etanercept seems to be safer, as it is a less potent inhibitor of TNF- $\alpha$ activity and less able to induce complement-dependent cytotoxicity and transmembrane TNF- $\alpha$ apoptosis [5]. Moreover, the antiviral effects of interferon and ribavirin were increased by etanercept in treatment-naïve patients with chronic HCV infection that presented a high sustained virologic response and a low frequency of adverse events [96]. On the other side, the progression of the cirrhosis and hepatocellular carcinoma could potentially be accelerated through the immunosuppression induced by TNF- $\alpha$-inhibitors [5]. Di Nuzzo et al. [97] reported two cases of hepatocellular carcinoma that developed in HCV patients with psoriasis with the cirrhotic disease during long-term etanercept treatment. In addition, adalimumab showed a safe profile in HCV-positive individuals affected by psoriasis. In a recent study on $20 \mathrm{HCV}$ patients with psoriasis treated with adalimumab for a median of 40 months, the log-rise of plasma HCV viral load was found only in 3 patients. The increase was not associated with concurrent hepatic cytolysis or cholestasis indexes and none of the patients reached the criteria for HCV reactivation [98]. To summarize, caution should be used in the administration of TNF $\alpha$ inhibitors in compensated patients, who need to be monitored by ultrasound imaging; but they are not suitable for patients with decompensated liver disease because of their increased risk of potentially serious infections [97].

\subsubsection{ANTI-IL-23}

Data on the safety of IL-23 inhibitors are limited, although their profile appears to be favorable [84].

\subsubsection{ANTI-IL-17}

Studies investigating the safety profile of IL-17 inhibitors in the context of HCV infection are limited to small case series with a short follow-up. In a study by Chiu et al. evaluating the safety profile of secukinumab among patients affected by psoriasis and concomitant $\mathrm{HBV}$ or HCV, one of $14(7.1 \%)$ patients reported increased HCV replication [85]. On the other hand, a patient with psoriasis and concomitant HBV-HCV infection was successfully treated with secukinumab and no adverse effects or reactivation were reported [86]. Overall, because robust data on the safety of secukinumab on HCV are lacking, it seems wise to consider patients with HCV infection receiving secukinumab as those who are treated with TNF- $\alpha$ inhibitors [84]. 


\subsubsection{ANTI-IL12/IL23}

Limited data are available on patients with concurrent $\mathrm{HCV}$ infections treated with ustekinumab. In a study by Chiu et al. [99] evaluating $4 \mathrm{HCV}$ patients affected by psoriasis under ustekinumab treatment, there was one reactivation and two cases of a slight rise in HCV-RNA. In two case reports, no reactivation was reported in psoriatic patients with concomitant HCV treated with ustekinumab. Moreover, long-term remission was maintained [100,101].

\subsubsection{ANTI-PDE4}

Few cases of HCV patients affected by psoriasis and treated with apremilast are described in the literature [74,102]. No cases of reactivation or elevation of liver enzymes are reported. The molecule is considered a safe option for patients with several conditions, such as active cancer or infection, for which conventional immunosuppressive therapy is contraindicated [90].

\subsubsection{ANTI-JAK}

No data were published during the last three years about the use of tofacitinib in patients with HCV infection and psoriasis.

\subsection{Hospital-Acquired Infections}

Hospital-acquired infections (HAIs) are more and more important on the scene of infectious diseases [19]. Although psoriasis has been shown to be an independent risk factor for serious and opportunistic infections, it has also been demonstrated that the introduction of a treatment with biologic drugs increases the risk of infection of about $55 \%[15,19,103]$. Moreover, the intravenous administration and the use of port-a-cath, increase the chance of developing bloodstream infections whenever the personnel handling the device has not been correctly trained [104]. An increased rate of HAIs is also correlated with the advanced age of the patients and hospital admission frequency [19]. In addition, psoriasis alone doubles the hospitalization rate for infection [19]. This could be also related to the fact that psoriatic patients are shown to have a 2.5-fold risk of developing chronic obstructive pulmonary disease and diabetes [19]. Moreover, IL-17 and IL-23 are pro-inflammatory cytokines involved in the defense of extracellular bacteria and fungi. Therefore, when IL-17 production is decreased, recurrent infections with Staphylococcus aureus and Candida albicans might be seen. Phase 2 and 3 studies on anti-IL-17 and anti-IL-23 did not show any increased risk of serious infections [105,106]; however, post-marketing studies highlighted an increased risk of opportunistic infections such as esophageal candidiasis, herpes zoster, pneumonia, and even Mycobacterium avium complex infections, especially with the use of anti-IL-23 drugs [107]. Hence, it is of utmost importance to attentively evaluate each patient for their infectious risk before beginning a treatment.

\subsection{COVID-19}

Whether psoriasis itself could confer susceptibility to SARS-CoV-2 virus infection is not known $[108,109]$. What is known is that systemic treatments, including synthetic or biologic disease-modifying antirheumatic drugs (DMARDs), have been associated with increased risk of infection, including respiratory tract viral infection [110,111]. In addition, patients with moderate-to-severe psoriasis are frequently affected by cardiometabolic comorbidities, such as obesity, diabetes mellitus, and hypertension, all representing negative prognostic factors for pneumonia by SARS-CoV-2 infection [112]. For these reasons, initiation of biologic therapy is not recommended in active SARS-CoV-2 infection and the transition to safer alternatives may be considered to avoid serious complications [113]. Several studies have assessed the incidence of SARS-CoV-2 infection in patients with psoriasis receiving systemic biological treatments and, apparently, there is no increased susceptibility to SARS-CoV-2 infection [112,114,115]. Studies have also been made reporting the risk of hospitalization, intensive care unit admission, and mortality due to COVID-19 in psoriasis 
patients treated with systemic therapies. No hospitalization or death was documented in 980 patients with psoriasis on biologics in a large cohort study by Gisondi et al. [116]. Moreover, several case reports and retrospective studies have been made about the course of COVID-19 in psoriasis patients receiving biological therapies [114,117-119]. In all the cases, full recovery from COVID-19 was reported after biologic treatment interruption. Favorable outcomes and no severe adverse effects were registered in patients that did not interrupt the biologic treatment, such as adalimumab and ustekinumab [118,119]. Other studies have shown that in presence of severe viral symptoms with high fever develop, the discontinuation of IL-17 inhibitors should be considered $[120,121]$. On the other hand, although IL-17 has an important role in mucosal immunity, preliminary studies by Wan et al. [122] and Tathiparthi et al. [123] did not prove any increased risk of either severe infection or negative outcome. Moreover, apremilast was shown having a good safety profile in COVID-19 affected patients, in fact, it does not favor either infection or cytokine storm, and it does not increase the risk of pulmonary fibrosis [124]. Factors to consider when selecting systemic treatment during COVID19-infection are summarized in Table 2.

Table 2. Factors to consider when selecting systemic treatment during COVID19-infection.

\begin{tabular}{ccc}
\hline Class of Drugs & Drug & COVID-19 \\
\hline TNF-a inhibitors & Etanercept & ++ \\
\hline & Adalimumab & ++ \\
\hline IL-23 inhibitors & Infliximab & ++ \\
\hline & Certolizumab & ++ \\
\hline IL-17 inhibitors & Guselkumab & ++ \\
\hline & Tildrakizumab & ++ \\
\hline IL-12/23 inhibitors & Risankizumab & + \\
\hline PDE4 inhibitors & Secukinumab & -+ \\
\hline JAK inhibitors & Ixekizumab & -+ \\
\hline & Brodalumab & ++ \\
\hline
\end{tabular}

Note: Two plus symbols (++) indicates preferred agents; one plus syndrome (+) indicates that the agent can be used; one plus symbol and one minus symbol (+ -) indicate that the drug can be used but is controversial; one minus symbol and one plus symbol $(-+)$ indicate that the drug is not preferred but can be used; one question mark and one plus symbol (?+) indicate that there are not enough data but the drug is likely safe to use; one question mark (?) indicates that there are not enough data; one minus symbol (-) indicates that use of that drug is controversial because there are not enough data; and $(x)$ indicates that the drug is contraindicated.

\section{Conclusions}

The presence and/or the possibility of comorbid conditions is fundamental when planning treatment and overall management of psoriatic patients, especially those with moderate-to-severe forms of the disease. With regard to infections, psoriasis itself represents a major risk factor. Moreover, the risk of concomitant infections may be increased by the administration of certain immunosuppressive drugs, so patients with psoriasis are recommended to be carefully screened for possible latent systemic infections. New emerging conditions, including the COVID-19 pandemic, have further highlighted the need to take into account the risk of infection in approaching such patients. According to the latest literature data and registers, using novel therapies, particularly anti-ILs and anti-PDE4, seem not to have a significant impact on the vulnerability of these patients to infections, thus representing a reassuring option in the management of the disease. 
Attention must, however, be kept high given the extensive use of these drugs, the presence of several comorbidities as well as the recrudescence of 'ancient' diseases, and the emergence of new infectious agents.

Author Contributions: Conceptualization, methodology, and writing—original draft preparation A.M. and M.C.; writing-data curation, L.M., F.L.P., Y.I. and G.N.; writing-review and editing and supervision, C.G. All authors have read and agreed to the published version of the manuscript.

Funding: This research received no external funding.

Institutional Review Board Statement: Not applicable.

Informed Consent Statement: Not applicable.

Data Availability Statement: Not applicable.

Conflicts of Interest: C.G. has received consultation fees and/or grants for research projects, advisory panels, and from giving educational lectures to Pfizer, Abbvie, Janssen-Cilag, Novartis, LEO Pharma, Bayer, Ely Lilly, Celgene, Merck Sharp \& Dome, Sanofi, Amgen, and Almirall. A.M., M.C., L.M., F.L.P., Y.I., and G.N. have no conflict of interest to disclose.

\section{References}

1. Armstrong, A.W.; Read, C. Pathophysiology, Clinical Presentation, and Treatment of Psoriasis: A Review. JAMA 2020, 323, 1945-1960. [CrossRef]

2. Dattilo, G.; Borgia, F.; Guarneri, C.; Casale, M.; Bitto, R.; Morabito, C.; Signorelli, S.; Katsiki, N.; Cannavò, S.P. Cardiovascular Risk in Psoriasis: Current State of the Art. Curr. Vasc. Pharmacol. 2019, 17, 85-91. [CrossRef]

3. Cannavò, S.P.; Guarneri, F.; Giuffrida, R.; Aragona, E.; Guarneri, C. Evaluation of Cutaneous Surface Parameters in Psoriatic Patients. Ski. Res. Technol. 2016, 23, 41-47. [CrossRef] [PubMed]

4. Ingrasciotta, Y.; Isgrò, V.; Ientile, V.; Tari, M.; Trifirò, G.; Guarneri, C. Are Patients with Psoriasis and Psoriatic Arthritis Undertreated? A Population-Based Study from Southern Italy. J. Clin. Med. 2021, 10, 3431. [CrossRef] [PubMed]

5. Schadler, E.D.; Ortel, B.; Mehlis, S.L. Biologics for the Primary Care Physician: Review and Treatment of Psoriasis. Dis.-A-Mon. DM 2019, 65, 51-90. [CrossRef]

6. Lv, J.; Zhou, D.; Wang, Y.; Zhao, J.; Chen, Z.; Zhang, J.; Di, T.; Hu, J.; Li, B.; Li, P.; et al. Quantitative Evaluation to Efficacy and Safety of Therapies for Psoriasis: A Network Meta-Analysis. Mol. Pain 2018, 14, 1744806918762205. [CrossRef]

7. Nestle, F.O.; Kaplan, D.H.; Barker, J. Psoriasis. N. Engl. J. Med. 2009, 361, 496-509. [CrossRef]

8. Salaffi, F.; Carlo, M.D.; Luchetti, M.M.; Donato, E.D.; Campanati, A.; Benfaremo, D.; Nicolini, M.; Carotti, M.; Giacchetti, A.; Ganzetti, G.; et al. A Validation Study of the Simple Psoriatic Arthritis Screening (SiPAS) Questionnaire to Screen Psoriasis Patients for Psoriatic Arthritis. Clin. Exp. Rheumatol. 2017, 36, 127-135. [PubMed]

9. Luchetti, M.M.; Benfaremo, D.; Campanati, A.; Molinelli, E.; Ciferri, M.; Cataldi, S.; Capeci, W.; Carlo, M.D.; Offidani, A.M.; Salaffi, F.; et al. Clinical Outcomes and Feasibility of the Multidisciplinary Management of Patients with Psoriatic Arthritis: Two-Year Clinical Experience of a Dermo-Rheumatologic Clinic. Clin. Rheumatol. 2018, 37, 2741-2749. [CrossRef]

10. Ganzetti, G.; Campanati, A.; Santarelli, A.; Pozzi, V.; Molinelli, E.; Minnetti, I.; Brisigotti, V.; Procaccini, M.; Emanuelli, M.; Offidani, A. Involvement of the Oral Cavity in Psoriasis: Results of a Clinical Study. Brit. J. Dermatol. 2015, 172, $282-285$. [CrossRef]

11. Ceccarelli, M.; Rullo, E.V.; Vaccaro, M.; Facciolà, A.; D’Aleo, F.; Paolucci, I.A.; Cannavò, S.P.; Cacopardo, B.; Pinzone, M.R.; Pellicanò, G.F.; et al. HIV-Associated Psoriasis: Epidemiology, Pathogenesis, and Management. Dermatol. Ther. 2019, 75, e12806. [CrossRef]

12. Ceccarelli, M.; Rullo, E.V.; Berretta, M.; Cacopardo, B.; Pellicanò, G.F.; Nunnari, G.; Guarneri, C. New Generation Biologics for the Treatment of Psoriasis and Psoriatic Arthritis. State of the Art and Considerations about the Risk of Infection. Dermatol. Ther. 2021, 34, e14660. [CrossRef]

13. Siegel, S.A.R.; Winthrop, K.L. In the Real World: Infections Associated with Biologic and Small Molecule Therapies in Psoriatic Arthritis and Psoriasis. Curr. Rheumatol. Rep. 2019, 21, 36. [CrossRef]

14. Abuabara, K.; Azfar, R.S.; Shin, D.B.; Neimann, A.L.; Troxel, A.B.; Gelfand, J.M. Cause-specific Mortality in Patients with Severe Psoriasis: A Population-based Cohort Study in the U.K. Brit. J. Dermatol. 2010, 163, 586-592. [CrossRef] [PubMed]

15. Takeshita, J.; Shin, D.B.; Ogdie, A.; Gelfand, J.M. Risk of Serious Infection, Opportunistic Infection, and Herpes Zoster among Patients with Psoriasis in the United Kingdom. J. Investig. Dermatol. 2018, 138, 1726-1735. [CrossRef] [PubMed]

16. Gisondi, P.; Talamonti, M.; Chiricozzi, A.; Piaserico, S.; Amerio, P.; Balato, A.; Bardazzi, F.; Pinton, P.C.; Campanati, A.; Cattaneo, A.; et al. Treat-to-Target Approach for the Management of Patients with Moderate-to-Severe Plaque Psoriasis: Consensus Recommendations. Dermatol. Ther. 2021, 11, 235-252. [CrossRef]

17. Li, X.; Andersen, K.M.; Chang, H.-Y.; Curtis, J.R.; Alexander, G.C. Comparative Risk of Serious Infections among Real-World Users of Biologics for Psoriasis or Psoriatic Arthritis. Ann. Rheum. Dis. 2020, 79, 285-291. [CrossRef] [PubMed] 
18. Yiu, Z.Z.N.; Parisi, R.; Lunt, M.; Warren, R.B.; Griffiths, C.E.M.; Langan, S.M.; Ashcroft, D.M. Risk of Hospitalization and Death Due to Infection in People with Psoriasis: A Population-based Cohort Study Using the Clinical Practice Research Datalink*. Brit. J. Dermatol. 2021, 184, 78-86. [CrossRef]

19. Hsu, D.Y.; Gordon, K.; Silverberg, J.I. Serious Infections in Hospitalized Patients with Psoriasis in the United States. J. Am. Acad. Dermatol. 2016, 75, 287-296. [CrossRef] [PubMed]

20. Marcianò, I.; Randazzo, M.P.; Panagia, P.; Intelisano, R.; Sgroi, C.; Ientile, V.; Cannavò, S.; Guarneri, C.; Reitano, P.; Spina, E.; et al. Real-World Use of Biological Drugs in Patients with Psoriasis/Psoriatic Arthritis: A Retrospective, Population-Based Study of Years 2010-2014 from Southern Italy. Giorn. Ital. Dermat. V 2018, 155, 441-451. [CrossRef]

21. Kaushik, S.B.; Lebwohl, M.G. Psoriasis: Which Therapy for Which Patient: Focus on Special Populations and Chronic Infections. J. Am. Acad. Dermatol. 2019, 80, 43-53. [CrossRef]

22. Houben, R.M.G.J.; Dodd, P.J. The Global Burden of Latent Tuberculosis Infection: A Re-Estimation Using Mathematical Modelling PLoS Med. 2016, 13, e1002152. [CrossRef] [PubMed]

23. Snast, I.; Atzmony, L.; Braun, M.; Hodak, E.; Pavlovsky, L. Risk for Hepatitis B and C Virus Reactivation in Patients with Psoriasis on Biologic Therapies: A Retrospective Cohort Study and Systematic Review of the Literature. J. Am. Acad. Dermatol. 2017, 77, 88-97.e5. [CrossRef] [PubMed]

24. Matsuzaki, G.; Umemura, M. Interleukin-17 as an Effector Molecule of Innate and Acquired Immunity against Infections Microbiol. Immunol. 2007, 51, 1139-1147. [CrossRef] [PubMed]

25. Doherty, S.D.; Voorhees, A.V.; Lebwohl, M.G.; Korman, N.J.; Young, M.S.; Hsu, S.; Foundation, N.P. National Psoriasis Foundation Consensus Statement on Screening for Latent Tuberculosis Infection in Patients with Psoriasis Treated with Systemic and Biologic Agents. J. Am. Acad. Dermatol. 2008, 59, 209-217. [CrossRef]

26. Amerio, P.; Amoruso, G.; Bardazzi, F.; Campanati, A.; Cassano, N.; Conti, A.; Gisondi, P.; Guarneri, C.; Mazzotta, A.; Piaserico, S.; et al. Detection and Management of Latent Tuberculosis Infections before Biologic Therapy for Psoriasis. J. Dermatol. Treat. 2012, 24, 305-311. [CrossRef] [PubMed]

27. Winthrop, K.L. Update on Tuberculosis and Other Opportunistic Infections Associated with Drugs Blocking Tumour Necrosis Factor $\alpha$. Ann. Rheum. Dis. 2005, 64, iv29. [CrossRef]

28. Keane, J.; Gershon, S.; Wise, R.P.; Mirabile-Levens, E.; Kasznica, J.; Schwieterman, W.D.; Siegel, J.N.; Braun, M.M. Tuberculosis Associated with Infliximab, a Tumor Necrosis Factor $\alpha-$ Neutralizing Agent. N. Engl. J. Med. 2001, 345, 1098-1104. [CrossRef]

29. Soare, A.; Gheorghiu, A.M.; Aramă, V.; Bumbăcea, D.; Dobrotă, R.; Oneaţă, R.; Pintilie, S.; Milicescu, M.; Ancuţa, I.; Martin, A.; et al. Risk of Active Tuberculosis in Patients with Inflammatory Arthritis Receiving TNF Inhibitors: A Look beyond the Baseline Tuberculosis Screening Protocol. Clin. Rheumatol. 2018, 37, 2391-2397. [CrossRef]

30. Solomon, D.H. The Comparative Safety and Effectiveness of TNF-Alpha Antagonists. J. Manag. Care Pharm. 2007, 13, 7-18. [CrossRef]

31. Almeida, d.R.F.C.; Penha, R.C.C.; do Nascimento Barbosa, L. Two Cases of Disseminated Tuberculosis after Negative Screening before Adalimumab Treatment for Immune-Mediated Inflammatory Diseases. Jaad Case Rep. 2019, 5, 1002-1005. [CrossRef]

32. Cantini, F.; Niccoli, L.; Goletti, D. Tuberculosis Risk in Patients Treated with Non-Anti-Tumor Necrosis Factor- $\alpha$ (TNF- $\alpha$ ) Targeted Biologics and Recently Licensed TNF- $\alpha$ Inhibitors: Data from Clinical Trials and National Registries. J. Rheumatol. Suppl. 2014, 91, 56-64. [CrossRef]

33. Tubach, F.; Salmon, D.; Ravaud, P.; Allanore, Y.; Goupille, P.; Bréban, M.; Pallot-Prades, B.; Pouplin, S.; Sacchi, A.; Chichemanian, R.M.; et al. Risk of Tuberculosis Is Higher with Anti-Tumor Necrosis Factor Monoclonal Antibody Therapy than with Soluble Tumor Necrosis Factor Receptor Therapy: The Three-year Prospective French Research Axed on Tolerance of Biotherapies Registry. Arthritis Rheum. 2009, 60, 1884-1894. [CrossRef] [PubMed]

34. Leonardi, C.; Papp, K.; Strober, B.; Thaçi, D.; Warren, R.B.; Tyring, S.; Arikan, D.; Karunaratne, M.; Valdecantos, W.C. Comprehensive Long-term Safety of Adalimumab from 18 Clinical Trials in Adult Patients with Moderate-to-severe Plaque Psoriasis. Brit. J. Dermatol. 2019, 180, 76-85. [CrossRef] [PubMed]

35. Curtis, J.R.; Mariette, X.; Gaujoux-Viala, C.; Blauvelt, A.; Kvien, T.K.; Sandborn, W.J.; Winthrop, K.; de Longueville, M.; Huybrechts, I.; Bykerk, V.P. Long-Term Safety of Certolizumab Pegol in Rheumatoid Arthritis, Axial Spondyloarthritis, Psoriatic Arthritis, Psoriasis and Crohn's Disease: A Pooled Analysis of 11,317 Patients across Clinical Trials. Rmd Open 2019, 5, e000942. [CrossRef] [PubMed]

36. Reich, K.; Griffiths, C.E.M.; Gordon, K.B.; Papp, K.A.; Song, M.; Randazzo, B.; Li, S.; Shen, Y.-K.; Han, C.; Kimball, A.B.; et al. Maintenance of Clinical Response and Consistent Safety Profile with up to 3 Years of Continuous Treatment with Guselkumab: Results from the VOYAGE 1 and VOYAGE 2 Trials. J. Am. Acad. Dermatol. 2020, 82, 936-945. [CrossRef] [PubMed]

37. Puig, L.; Tsai, T.-F.; Bhutani, T.; Uy, J.; Ramachandran, P.; Song, M.; You, Y.; Gooderham, M.; Lebwohl, M. Safety in Moderate-tosevere Plaque Psoriasis Patients with Latent Tuberculosis Treated with Guselkumab and Anti-tuberculosis Treatments Concomitantly: Results from Pooled Phase 3 VOYAGE 1 \& VOYAGE 2 Trials. J. Eur. Acad. Dermatol. 2020, 34, 1744-1749. [CrossRef]

38. Reich, K.; Armstrong, A.W.; Langley, R.G.; Flavin, S.; Randazzo, B.; Li, S.; Hsu, M.-C.; Branigan, P.; Blauvelt, A. Guselkumab versus Secukinumab for the Treatment of Moderate-to-Severe Psoriasis (ECLIPSE): Results from a Phase 3, Randomised Controlled Trial. Lancet 2019, 394, 831-839. [CrossRef] 
39. Blauvelt, A.; Leonardi, C.L.; Gooderham, M.; Papp, K.A.; Philipp, S.; Wu, J.J.; Igarashi, A.; Flack, M.; Geng, Z.; Wu, T.; et al. Efficacy and Safety of Continuous Risankizumab Therapy vs Treatment Withdrawal in Patients With Moderate to Severe Plaque Psoriasis. Jama Dermatol. 2020, 156, 649-658. [CrossRef]

40. Huang, Y.-W.; Tsai, T.-F. A Drug Safety Evaluation of Risankizumab for Psoriasis. Expert Opin. Drug. Saf. 2020, 19, 395-402. [CrossRef]

41. Reich, K.; Warren, R.B.; Iversen, L.; Puig, L.; Pau-Charles, I.; Igarashi, A.; Ohtsuki, M.; Falqués, M.; Harmut, M.; Rozzo, S.; et al. Long-term Efficacy and Safety of Tildrakizumab for Moderate-to-severe Psoriasis: Pooled Analyses of Two Randomized Phase III Clinical Trials (ReSURFACE 1 and ReSURFACE 2) through 148 Weeks. Brit. J. Dermatol. 2020, 182, 605-617. [CrossRef]

42. Wu, C.-Y.; Chiu, H.-Y.; Tsai, T.-F. The Seroconversion Rate of QuantiFERON-TB Gold In-Tube Test in Psoriatic Patients Receiving Secukinumab and Ixekizumab, the Anti-Interleukin-17A Monoclonal Antibodies. PLoS ONE 2019, 14, e0225112. [CrossRef] [PubMed]

43. Bissonnette, R.; Luger, T.; Thaçi, D.; Toth, D.; Lacombe, A.; Xia, S.; Mazur, R.; Patekar, M.; Charef, P.; Milutinovic, M.; et al Secukinumab Demonstrates High Sustained Efficacy and a Favourable Safety Profile in Patients with Moderate-to-severe Psoriasis through 5 Years of Treatment (SCULPTURE Extension Study). J. Eur. Acad. Dermatol. 2018, 32, 1507-1514. [CrossRef]

44. Ribero, S.; Licciardello, M.; Quaglino, P.; Dapavo, P. Efficacy and Safety of Secukinumab in Patients with Plaque Psoriasis and Latent Tuberculosis. Case Rep. Dermatol. 2019, 11, 23-28. [CrossRef]

45. Kammüller, M.; Tsai, T.-F.; Griffiths, C.E.; Kapoor, N.; Kolattukudy, P.E.; Brees, D.; Chibout, S.-D.; Safi, J., Jr.; Fox, T. Inhibition of IL-17A by Secukinumab Shows No Evidence of Increased Mycobacterium Tuberculosis Infections. Clin. Transl. Immunol. 2017, 6, e152. [CrossRef]

46. Yamaguchi, Y.; Takatsu, N.; Ootaki, K.; Nakagawa, H. Long-term Safety of Brodalumab in Japanese Patients with Plaque Psoriasis: An Open-label Extension Study. J. Dermatol. 2020, 47, 569-577. [CrossRef] [PubMed]

47. Leonardi, C.; Reich, K.; Foley, P.; Torii, H.; Gerdes, S.; Guenther, L.; Gooderham, M.; Ferris, L.K.; Griffiths, C.E.M.; ElMaraghy, H.; et al. Efficacy and Safety of Ixekizumab Through 5 Years in Moderate-to-Severe Psoriasis: Long-Term Results from the UNCOVER-1 and UNCOVER-2 Phase-3 Randomized Controlled Trials. Dermatol. Ther. 2020, 10, 431-447. [CrossRef] [PubMed]

48. Tsai, T.-F.; Chiu, H.-Y.; Song, M.; Chan, D. A Case of Latent Tuberculosis Reactivation in a Patient Treated with Ustekinumab without Concomitant Isoniazid Chemoprophylaxis in the PEARL Trial. Brit. J. Dermatol. 2013, 168, 444-446. [CrossRef]

49. Cho, S.I.; Kang, S.; Kim, Y.E.; Lee, J.Y.; Jo, S.J. Ustekinumab Does Not Increase Tuberculosis Risk: Results from a National Database in South Korea. J. Am. Acad. Dermatol. 2019, 82, 1243-1245. [CrossRef]

50. Hsiao, C.-Y.; Chiu, H.-Y.; Wang, T.-S.; Tsai, T.-F. Serial QuantiFERON-TB Gold Testing in Patients with Psoriasis Treated with Ustekinumab. PLoS ONE 2017, 12, e0184178. [CrossRef]

51. Kavanaugh, A.; Gladman, D.D.; Edwards, C.J.; Schett, G.; Guerette, B.; Delev, N.; Teng, L.; Paris, M.; Mease, P.J. Long-Term Experience with Apremilast in Patients with Psoriatic Arthritis: 5-Year Results from a PALACE 1-3 Pooled Analysis. Arthritis Res. Ther. 2019, 21, 118. [CrossRef] [PubMed]

52. Schett, G.; Wollenhaupt, J.; Papp, K.; Joos, R.; Rodrigues, J.F.; Vessey, A.R.; Hu, C.; Stevens, R.; de Vlam, K.L. Oral Apremilast in the Treatment of Active Psoriatic Arthritis: Results of a Multicenter, Randomized, Double-blind, Placebo-controlled Study Arthritis Rheum. 2012, 64, 3156-3167. [CrossRef] [PubMed]

53. Hagberg, K.W.; Persson, R.; Vasilakis-Scaramozza, C.; Niemcryk, S.; Peng, M.; Paris, M.; Lindholm, A.; Jick, S. Herpes Zoster, Hepatitis C, and Tuberculosis Risk with Apremilast Compared to Biologics, DMARDs and Corticosteroids to Treat Psoriasis and Psoriatic Arthritis. Clin. Epidemiol. 2020, 12, 153-161. [CrossRef]

54. Papp, K.A.; Krueger, J.G.; Feldman, S.R.; Langley, R.G.; Thaci, D.; Torii, H.; Tyring, S.; Wolk, R.; Gardner, A.; Mebus, C.; et al Tofacitinib, an Oral Janus Kinase Inhibitor, for the Treatment of Chronic Plaque Psoriasis: Long-Term Efficacy and Safety Results from 2 Randomized Phase-III Studies and 1 Open-Label Long-Term Extension Study. J. Am. Acad. Dermatol. 2016, 74, 841-850. [CrossRef]

55. Pesu, M.; Candotti, F.; Husa, M.; Hofmann, S.R.; Notarangelo, L.D.; O'Shea, J.J. Jak3, Severe Combined Immunodeficiency, and a New Class of Immunosuppressive Drugs. Immunol. Rev. 2005, 203, 127-142. [CrossRef]

56. Tian, F.; Chen, Z.; Xu, T. Efficacy and Safety of Tofacitinib for the Treatment of Chronic Plaque Psoriasis: A Systematic Review and Meta-Analysis. J. Int. Med. Res. 2019, 47, 2342-2350. [CrossRef]

57. Cohen, S.B.; Tanaka, Y.; Mariette, X.; Curtis, J.R.; Lee, E.B.; Nash, P.; Winthrop, K.L.; Charles-Schoeman, C.; Thirunavukkarasu, K.; DeMasi, R.; et al. Long-Term Safety of Tofacitinib for the Treatment of Rheumatoid Arthritis up to 8.5 Years: Integrated Analysis of Data from the Global Clinical Trials. Ann. Rheum. Dis. 2017, 76, 1253-1262. [CrossRef] [PubMed]

58. Winthrop, K.L.; Park, S.-H.; Gul, A.; Cardiel, M.H.; Gomez-Reino, J.J.; Tanaka, Y.; Kwok, K.; Lukic, T.; Mortensen, E.; de Leon, D.P.; et al. Tuberculosis and Other Opportunistic Infections in Tofacitinib-Treated Patients with Rheumatoid Arthritis. Ann. Rheum. Dis. 2016, 75, 1133-1138. [CrossRef] [PubMed]

59. Alpalhão, M.; Borges-Costa, J.; Filipe, P. Psoriasis in HIV Infection: An Update. Int. J. STD AIDS 2019, 30, 596-604. [CrossRef]

60. Simone, C.D.; Perino, F.; Caldarola, G.; D'Agostino, M.; Peris, K. Treatment of Psoriasis with Etanercept in Immunocompromised Patients: Two Case Reports. J. Int. Med. Res. 2016, 44, 67-71. [CrossRef]

61. Morar, N.; Willis-Owen, S.A.; Maurer, T.; Bunker, C.B. HIV-Associated Psoriasis: Pathogenesis, Clinical Features, and Management. Lancet Infect. Dis. 2010, 10, 470-478. [CrossRef] 
62. Gallitano, S.M.; McDermott, L.; Brar, K.; Lowenstein, E. Use of Tumor Necrosis Factor (TNF) Inhibitors in Patients with HIV/AIDS. J. Am. Acad. Dermatol. 2016, 74, 974-980. [CrossRef]

63. Cepeda, E.J.; Williams, F.M.; Ishimori, M.L.; Weisman, M.H.; Reveille, J.D. The Use of Anti-Tumour Necrosis Factor Therapy in HIV-Positive Individuals with Rheumatic Disease. Ann. Rheum. Dis. 2008, 67, 710-712. [CrossRef] [PubMed]

64. Lindsey, S.F.; Weiss, J.; Lee, E.S.; Romanelli, P. Treatment of Severe Psoriasis and Psoriatic Arthritis with Adalimumab in an HIV-Positive Patient. J. Drugs Dermatol. JDD 2014, 13, 869-871. [PubMed]

65. Wallis, R.S.; Kyambadde, P.; Johnson, J.L.; Horter, L.; Kittle, R.; Pohle, M.; Ducar, C.; Millard, M.; Mayanja-Kizza, H.; Whalen, C.; et al. A Study of the Safety, Immunology, Virology, and Microbiology of Adjunctive Etanercept in HIV-1-Associated Tuberculosis. AIDS 2004, 18, 257-264. [CrossRef] [PubMed]

66. Bardazzi, F.; Magnano, M.; Campanati, A.; Loconsole, F.; Carpentieri, A.; Potenza, C.; Bernardini, N.; Lernia, V.D.; Carrera, C.; Raone, B.; et al. Biologic Therapies in HIV-Infected Patients with Psoriasis: An Italian Experience. Acta Derm-Venereol. 2017, 97, 989-990. [CrossRef] [PubMed]

67. Bartos, G.; Cline, A.; Beroukhim, K.; Burrall, B.A.; Feldman, S.R. Current Biological Therapies for Use in HIV-Positive Patients with Psoriasis: Case Report of Guselkumab Used and Review. Dermatol. Online J. 2018, 24, 2. [CrossRef]

68. Lernia, V.D.; Casanova, D.M.; Garlassi, E. Secukinumab in an HIV-positive Patient with Psoriasis. Jddg J. Der. Dtsch. Dermatol. Ges. 2019, 17, 646-648. [CrossRef]

69. Pangilinan, M.C.G.; Sermswan, P.; Asawanonda, P. Use of Anti-IL-17 Monoclonal Antibodies in HIV Patients with Erythrodermic Psoriasis. Case Rep. Dermatol. 2020, 12, 132-137. [CrossRef]

70. Montes-Torres, A.; Aparicio, G.; Rivera, R.; Vilarrasa, E.; Marcellán, M.; Notario, J.; Soria, C.; Belinchón, I.; de la Cueva, P.; Ferrán, M.; et al. Safety and Effectiveness of Conventional Systemic Therapy and Biological Drugs in Patients with Moderate to Severe Psoriasis and HIV Infection: A Retrospective Multicenter Study. J. Dermatol. Treat. 2019, 30, 461-465. [CrossRef]

71. Saeki, H.; Ito, T.; Hayashi, M.; Fukuchi, O.; Umezawa, Y.; Nobeyama, Y.; Teruya, K.; Nakagawa, H. Successful Treatment of Ustekinumab in a Severe Psoriasis Patient with Human Immunodeficiency Virus Infection. J. Eur. Acad. Dermatol. Venereol. JEADV 2015, 29, 1653-1655. [CrossRef]

72. Shah, B.; Mistry, D.; Chaudhary, N. Apremilast in People Living with HIV with Psoriasis Vulgaris: A Case Report. Indian J. Derm. 2019, 64, 242. [CrossRef]

73. Zarbafian, M.; Cote, B.; Richer, V. Treatment of Moderate to Severe Psoriasis with Apremilast over 2 Years in the Context of Long-Term Treated HIV Infection: A Case Report. Sage Open Med. Case Rep. 2019, 7, 2050313X19845193. [CrossRef] [PubMed]

74. Reddy, S.P.; Shah, V.V.; Wu, J.J. Apremilast for a Psoriasis Patient with HIV and Hepatitis C. J. Eur. Acad. Dermatol. Venereol. JEADV 2017, 31, e481-e482. [CrossRef] [PubMed]

75. Manfreda, V.; Esposito, M.; Campione, E.; Bianchi, L.; Giunta, A. Apremilast Efficacy and Safety in a Psoriatic Arthritis Patient Affected by HIV and HBV Virus Infections. Postgrad Med. 2019, 131, 239-240. [CrossRef]

76. Cohen, A.D.; Weitzman, D.; Birkenfeld, S.; Dreiher, J. Psoriasis Associated with Hepatitis C but Not with Hepatitis B. Dermatology 2010, 220, 218-222. [CrossRef]

77. Kanada, K.N.; Schupp, C.W.; Armstrong, A.W. Association between Psoriasis and Viral Infections in the United States: Focusing on Hepatitis B, Hepatitis C and Human Immunodeficiency Virus. J. Eur. Acad. Dermatol. 2013, 27, 1312-1316. [CrossRef] [PubMed]

78. European Association for the Study of the Liver. EASL 2017 Clinical Practice Guidelines on the Management of Hepatitis B Virus Infection. J. Hepatol. 2017, 67, 370-398. [CrossRef]

79. Nicoletta, B.; Alessandra, N.; Nevena, S.; Tolino, E.; Colapietra, D.; Claudio, M.; Concetta, P. Management of Psoriatic Patients in Biologic Treatment Associated with Infectious Comorbidities. Adv. Dermatol. Allergol. 2020, 37, 417-421. [CrossRef] [PubMed]

80. Pérez-Alvarez, R.; Díaz-Lagares, C.; García-Hernández, F.; Lopez-Roses, L.; Brito-Zerón, P.; Pérez-de-Lis, M.; Retamozo, S.; Bové, A.; Bosch, X.; Sanchez-Tapias, J.-M.; et al. Hepatitis B Virus (HBV) Reactivation in Patients Receiving Tumor Necrosis Factor (TNF)-Targeted Therapy. Medicine 2011, 90, 359-371. [CrossRef] [PubMed]

81. French, J.B.; Bonacini, M.; Ghabril, M.; Foureau, D.; Bonkovsky, H.L. Hepatotoxicity Associated with the Use of Anti-TNF- $\alpha$ Agents. Drug Saf. 2016, 39, 199-208. [CrossRef] [PubMed]

82. Duncan, J.R.; Orlowski, T.J.; Elewski, B.E. Safety of Guselkumab in Hepatitis B Virus Infection. Dermatol. Online J. 2019, 25, 10. [CrossRef]

83. Song, E.J.; Whitman, P.; Samsel, J. The Use of Ustekinumab and Guselkumab in a Pediatric Psoriasis Patient with Active Hepatitis B Infection. Jaad Case Rep. 2020, 8, 37-39. [CrossRef] [PubMed]

84. Piaserico, S.; Messina, F.; Russo, F.P. Managing Psoriasis in Patients with HBV or HCV Infection: Practical Considerations. Am. J. Clin. Dermatol. 2019, 20, 829-845. [CrossRef]

85. Chiu, H.; Hui, R.; Huang, Y.; Huang, R.; Chen, K.; Tsai, Y.; Lai, P.; Wang, T.; Tsai, T. Safety Profile of Secukinumab in Treatment of Patients with Psoriasis and Concurrent Hepatitis B or C: A Multicentric Prospective Cohort Study. Acta Dermato Venereol. 2018, 98 , 829-834. [CrossRef] [PubMed]

86. Peccerillo, F.; Odorici, G.; Pellacani, G.; Conti, A. Secukinumab: A Positive Outcome in a Patient with Severe Psoriasis and HBV-HCV Co-Infection. Dermatol. Ther. 2018, 31, e12601. [CrossRef] [PubMed]

87. Bevans, S.L.; Mayo, T.T.; Elewski, B.E. Safety of Secukinumab in Hepatitis B Virus. J. Eur. Acad. Dermatol. 2018, 32, e120-e121. [CrossRef] 
88. Lora, V.; Graceffa, D.; Felice, C.D.; Morrone, A.; Bonifati, C. Treatment of Severe Psoriasis with Ixekizumab in a Liver Transplant Recipient with Concomitant Hepatitis B Virus Infection. Dermatol. Ther. 2019, 32, 346-352. [CrossRef]

89. Koike, Y.; Fujiki, Y.; Higuchi, M.; Fukuchi, R.; Kuwatsuka, S.; Murota, H. An Interleukin-17 Inhibitor Successfully Treated a Complicated Psoriasis and Psoriatic Arthritis Patient with Hepatitis B Virus Infection and End-Stage Kidney Disease on Hemodialysis. Jaad Case Rep. 2019, 5, 150-152. [CrossRef]

90. Torres, T.; Puig, L. Apremilast: A Novel Oral Treatment for Psoriasis and Psoriatic Arthritis. Am. J. Clin. Dermatol. 2018, 19, 23-32. [CrossRef]

91. Kanazawa, K.; Aikawa, T.; Tsuda, F.; Okamoto, H. Hepatitis C Virus Infection in Patients With Psoriasis. Arch Dermatol. 1996, 132, 1391-1392. [CrossRef] [PubMed]

92. Chun, K.; Afshar, M.; Audish, D.; Kabigting, F.; Paik, A.; Gallo, R.; Hata, T. Hepatitis C May Enhance Key Amplifiers of Psoriasis. J. Eur. Acad. Dermatol. Venereol. 2017, 31, 672-678. [CrossRef] [PubMed]

93. European Association for the Study of the Liver. EASL Recommendations on Treatment of Hepatitis C 2018. J. Hepatol. 2018, 69, 461-511. [CrossRef]

94. Bojito-Marrero, L.; Pyrsopoulos, N. Hepatitis B and Hepatitis C Reactivation in the Biologic Era. J. Clin. Transl. Hepatol. 2014, 2, 240-246. [CrossRef]

95. Kishihara, Y.; Hayashi, J.; Yoshimura, E.; Yamaji, K.; Nakashima, K.; Kashiwagi, S. IL-1 $\beta$ and TNF- $\alpha$ Produced by Peripheral Blood Mononuclear Cells before and during Interferon Therapy in Patients with Chronic Hepatitis C. Digest Dis. Sci. 1996, 41, 315-321. [CrossRef]

96. Zein, N.N.; Etanercept Study Group. Etanercept as an Adjuvant to Interferon and Ribavirin in Treatment-Naive Patients with Chronic Hepatitis C Virus Infection: A Phase 2 Randomized, Double-Blind, Placebo-Controlled Study. J. Hepatol. 2005, 42, 315-322. [CrossRef]

97. Nuzzo, S.D.; Boccaletti, V.; Fantini, C.; Cortelazzi, C.; Missale, G.; Fabrizi, G.; Lotti, T.; Hercogová, J.; Pagliarello, C. Are Anti-TNF$\alpha$ Agents Safe for Treating Psoriasis in Hepatitis C Virus Patients with Advanced Liver Disease? Case Reports and Review of the Literature. Dermatology 2016, 232, 102-106. [CrossRef]

98. Piaserico, S.; Dapavo, P.; Conti, A.; Gisondi, P.; Russo, F.P. Adalimumab Is a Safe Option for Psoriasis Patients with Concomitant Hepatitis B or C Infection: A Multicentre Cohort Study of 37 Patients and Review of the Literature. J. Eur. Acad. Dermatol. 2017, 31, 1853-1859. [CrossRef]

99. Chiu, H.-Y.; Chen, C.-H.; Wu, M.-S.; Cheng, Y.-P.; Tsai, T.-F. The Safety Profile of Ustekinumab in the Treatment of Patients with Psoriasis and Concurrent Hepatitis B or C. Brit. J. Dermatol. 2013, 169, 1295-1303. [CrossRef]

100. Abuchar, A.; Vitiello, M.; Kerdel, F.A. Psoriasis Treated with Ustekinumab in a Patient with Hepatitis C. Int. J. Dermatol. 2013, 52, 381-382. [CrossRef] [PubMed]

101. Kikuchi, S.; Umezawa, Y.; Chihara, M.; Asahina, A.; Nakagawa, H. Case of Psoriatic Patient Who Maintains Long-term Remission after Anti-hepatitis C Virus Agents and Ustekinumab Treatment. J. Dermatol. 2018, 45, e59-e60. [CrossRef]

102. Jeon, C.; Nakamura, M.; Sekhon, S.; Yan, D.; Wu, J.J.; Liao, W.; Bhutani, T. Generalized Pustular Psoriasis Treated with Apremilast in a Patient with Multiple Medical Comorbidities. Jaad Case Rep. 2017, 3, 495-497. [CrossRef]

103. Haddad, A.; Li, S.; Thavaneswaran, A.; Cook, R.J.; Chandran, V.; Gladman, D.D. The Incidence and Predictors of Infection in Psoriasis and Psoriatic Arthritis: Results from Longitudinal Observational Cohorts. J. Rheumatol. 2016, 43, 362-366. [CrossRef]

104. Saraswathy, T.; Nalliah, S.; Rosliza, A.M.; Ramasamy, S.; Jalina, K.; Shahar, H.K.; Amin-Nordin, S. Applying Interprofessional Simulation to Improve Knowledge, Attitude and Practice in Hospital-Acquired Infection Control among Health Professionals. BMC Med. Educ. 2021, 21, 482. [CrossRef]

105. Nakamura, M.; Lee, K.; Jeon, C.; Sekhon, S.; Afifi, L.; Yan, D.; Lee, K.; Bhutani, T. Guselkumab for the Treatment of Psoriasis: A Review of Phase III Trials. Dermatol. Ther. 2017, 7, 281-292. [CrossRef] [PubMed]

106. Deodhar, A.; Gottlieb, A.B.; Boehncke, W.-H.; Dong, B.; Wang, Y.; Zhuang, Y.; Barchuk, W.; Xu, X.L.; Hsia, E.C.; Group, C.S. Efficacy and Safety of Guselkumab in Patients with Active Psoriatic Arthritis: A Randomised, Double-Blind, Placebo-Controlled, Phase 2 Study. Lancet 2018, 391, 2213-2224. [CrossRef]

107. Deodhar, A.; Mease, P.J.; McInnes, I.B.; Baraliakos, X.; Reich, K.; Blauvelt, A.; Leonardi, C.; Porter, B.; Gupta, A.D.; Widmer, A.; et al. Long-Term Safety of Secukinumab in Patients with Moderate-to-Severe Plaque Psoriasis, Psoriatic Arthritis, and Ankylosing Spondylitis: Integrated Pooled Clinical Trial and Post-Marketing Surveillance Data. Arthritis Res. Ther. 2019, 21, 888. [CrossRef] [PubMed]

108. Gisondi, P.; Bellinato, F.; Chiricozzi, A.; Girolomoni, G. The Risk of COVID-19 Pandemic in Patients with Moderate to Severe Plaque Psoriasis Receiving Systemic Treatments. Nato Adv. Sci. Inst. Se 2020, 8, 728. [CrossRef] [PubMed]

109. Talamonti, M.; Galluzzo, M.; Chiricozzi, A.; Quaglino, P.; Fabbrocini, G.; Gisondi, P.; Marzano, A.V.; Potenza, C.; Conti, A.; Parodi, A.; et al. Management of Biological Therapies for Chronic Plaque Psoriasis during COVID-19 Emergency in Italy. J. Eur. Acad. Dermatol. 2020, 34, e770-e772. [CrossRef] [PubMed]

110. Rademaker, M.; Agnew, K.; Anagnostou, N.; Andrews, M.; Armour, K.; Baker, C.; Foley, P.; Gebauer, K.; Gupta, M.; Marshman, G.; et al. Psoriasis and infection. A clinical practice narrative. Australas. J. Dermatol. 2019, 60, 91-98. [CrossRef]

111. Meduri, A.; Oliverio, G.W.; Mancuso, G.; Giuffrida, A.; Guarneri, C.; Rullo, E.V.; Nunnari, G.; Aragona, P. Ocular Surface Manifestation of COVID-19 and Tear Film Analysis. Sci. Rep. 2020, 10, 20178. [CrossRef] [PubMed] 
112. Piaserico, S.; Gisondi, P.; Cazzaniga, S.; Naldi, L. Lack of Evidence for an Increased Risk of Severe COVID-19 in Psoriasis Patients on Biologics: A Cohort Study from Northeast Italy. Am. J. Clin. Dermatol. 2020, 21, 749-751. [CrossRef]

113. Ricardo, J.W.; Lipner, S.R. Considerations for Safety in the Use of Systemic Medications for Psoriasis and Atopic Dermatitis during the COVID-19 Pandemic. Dermatol. Ther. 2020, 33. [CrossRef] [PubMed]

114. Strippoli, D.; Barbagallo, T.; Prestinari, F.; Russo, G.; Fantini, F. Biologic Agents in Psoriasis: Our Experience during Coronavirus Infection. Int. J. Dermatol. 2020, 59, e266-e267. [CrossRef]

115. Damiani, G.; Allocco, F.; Network, Y.D.I.; Malagoli, P. COVID-19 Vaccination and Patients with Psoriasis under Biologics: Real-life Evidence on Safety and Effectiveness from Italian Vaccinated Healthcare Workers. Clin. Exp. Dermatol. 2021, 46, 1106-1108. [CrossRef]

116. Gisondi, P.; Zaza, G.; Giglio, M.D.; Rossi, M.; Iacono, V.; Girolomoni, G. Risk of Hospitalization and Death from COVID-19 Infection in Patients with Chronic Plaque Psoriasis Receiving a Biological Treatment and Renal Transplanted Recipients in Maintenance Immunosuppressive Treatment. J. Am. Acad. Dermatol. 2020, 83, 285-287. [CrossRef]

117. Lernia, V.D.; Bombonato, C.; Motolese, A. COVID-19 in an Elderly Patient Treated with Secukinumab. Dermatol. Ther. 2020, 33, e13580. [CrossRef]

118. Vispi, M.; Corradin, T.; Peccianti, C.; Feci, L.; Casini, L.; Pisani, C.; Fabbroni, S.; Corsetti, P.; Croatto, M.; Pellegrino, M. Psoriasis, Biological Drugs and Coronavirus Disease 2019: Real Life Experience of Two Italian Provinces. Dermatol. Rep. 2020, $12,8642$. [CrossRef]

119. Conti, A.; Lasagni, C.; Bigi, L.; Pellacani, G. Evolution of COVID-19 Infection in Four Psoriatic Patients Treated with Biological Drugs. J. Eur. Acad. Dermatol. 2020, 34, e360-e361. [CrossRef]

120. Kearns, D.G.; Uppal, S.; Chat, V.S.; Wu, J.J. Use of Systemic Therapies for Psoriasis in the COVID-19 Era. J. Dermatol. Treat 2021, 1-4. [CrossRef] [PubMed]

121. Chat, V.S.; Uppal, S.K.; Kearns, D.G.; Wu, J.J. Clinical Management of Psoriasis Patients during the COVID-19 Pandemic. J. Dermatol. Treat. 2020, 1-2. [CrossRef] [PubMed]

122. Wan, M.T.; Shin, D.B.; Winthrop, K.L.; Gelfand, J.M. The Risk of Respiratory Tract Infections and Symptoms in Psoriasis Patients Treated with IL-17-Pathway Inhibiting Biologics: A Meta-Estimate of Pivotal Trials Relevant to Decision-Making during the COVID-19 Pandemic. J. Am. Acad. Dermatol. 2020, 83, 677-679. [CrossRef] [PubMed]

123. Thatiparthi, A.; Martin, A.; Liu, J.; Egeberg, A.; Wu, J.J. Biologic Treatment Algorithms for Moderate-to-Severe Psoriasis with Comorbid Conditions and Special Populations: A Review. Am. J. Clin. Dermatol. 2021, 22, 425-442. [CrossRef] [PubMed]

124. Mugheddu, C.; Pizzatti, L.; Sanna, S.; Atzori, L.; Rongioletti, F. COVID-19 Pulmonary Infection in Erythrodermic Psoriatic Patient with Oligodendroglioma: Safety and Compatibility of Apremilast with Critical Intensive Care Management. J. Eur. Acad. Dermatol. 2020, 34, e376-e378. [CrossRef] 